\title{
Corporate Social Responsibility - A Study on Mangalore Refinery and Petrochemicals Limited (MRPL)
}

\author{
Bindhu D. ${ }^{1} \& \mathrm{Niyaz}^{2}$ \\ ${ }^{1}$ Research Scholar, College of Management \& Commerce, Srinivas University, \\ Mangalore, India-575001 \\ OrcidID:0000-0003-3714-3331; Email: bindhuranjith11@ gmail.com \\ ${ }^{2}$ Research Professor, College of Management \& Commerce, Srinivas University, \\ Mangalore, India-575001 \\ OrcidID: 0000-0003-4568-1658; Email: niyaz0191@gmail.com
}

Area of the Paper: Management

Type of the Paper: Research Case Study

Type of Review: Peer Reviewed as per $|\mathrm{C}| \mathrm{O}|\mathrm{P}| \mathrm{E} \mid$ guidance.

Indexed In: OpenAIRE.

DOI: https://doi.org/10.5281/zenodo.5806344

Google Scholar Citation: IJCSBE

\section{How to Cite this Paper:}

Bindhu, D., \& Niyaz, (2021). Corporate Social Responsibility - A Study on Mangalore Refinery and Petrochemicals Limited (MRPL). International Journal of Case Studies in Business, IT, and Education (IJCSBE), 5(2), 375-385. DOI: https://doi.org/10.5281/zenodo.5806344

International Journal of Case Studies in Business, IT and Education (IJCSBE) A Refereed International Journal of Srinivas University, India.

Crossref DOI : https://doi.org/10.47992/IJCSBE.2581.6942.0142

(C) With Authors.

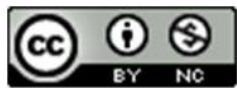

This work is licensed under a Creative Commons Attribution Non-Commercial 4.0 International License subject to proper citation to the publication source of the work.

Disclaimer: The scholarly papers as reviewed and published by the Srinivas Publications (S.P.), India are the views and opinions of their respective authors and are not the views or opinions of the S.P. The S.P. disclaims of any harm or loss caused due to the published content to any party. 


\title{
Corporate Social Responsibility - A Study on Mangalore Refinery and Petrochemicals Limited (MRPL)
}

\author{
Bindhu D. ${ }^{1} \& \mathrm{Niyaz}^{2}$ \\ ${ }^{1}$ Research Scholar, College of Management \& Commerce, Srinivas University, \\ Mangalore, India-575001 \\ OrcidID:0000-0003-3714-3331; Email: bindhuranjith11@ gmail.com \\ ${ }^{2}$ Research Professor, College of Management \& Commerce, Srinivas University, \\ Mangalore, India-575001 \\ OrcidID: 0000-0003-4568-1658; Email: niyaz0191@ gmail.com
}

\begin{abstract}
Purpose: In a competitive business climate, primarily determined by the passage of something like the Indian Companies Act-2013, corporate Sustainability obligations must be followed. Currently, corporations must strike a balance between their financial and economic objectives, as well as maximizing shareholder value while also providing social benefits to the community and helping to safeguard the environment. CSR covers actions for a better society authorized under the Companies Act, 2013 such as health, education, women's empowerment, and environmental sustainability.
\end{abstract}

Methodology: Secondary data from research journal papers and specific websites on the research subject area was used in this research paper. These findings provide a conceptual framework for CSR operations, as well as an assessment of how MRPL Co. fulfils its commitments to all stakeholders, including particular activities, programmes, and projects. The study focuses on the company's CSR implementation in order to determine the business's focal area.

Findings: The analytical framework offered an overview of the organization's CSR activities and expenditures, in addition to key focus areas and progress in each area of an organisation. Practical Implications: From a practical standpoint, the proposed framework provides practitioners with a tool that explicitly gauges their companies' CSR maturity. Stakeholder relations have been critical in the development of many poor regions within India for the MRPL Company. The idea of sustainable growth lies at the heart of both their business choices and Corporate Social Responsibility efforts.

Originality/Value: Using this study approach, we can find out what variables explain the different levels of CSR integration into a company's strategy and quantify the current maturity level.

Paper Type: Conceptual Research

Keywords: Corporate Social Responsibility, Stakeholders, Company, Environment, SWOC analysis

\section{INTRODUCTION :}

Customers add to the brand value of a socially conscious firm by raising potential earnings and goodwill. As a result, Strategies help businesses improve their image, which affects brand equity [1]. CSR is a responsible business framework that allows a company that are socially answerable to its shareholders, employees, and the general public [2]. Organizations should always be conscious of their ramifications on whole elements of society, counting economic, social, and environmental concerns, by practising corporate social responsibility, also known as corporate stewardship. The term corporate social responsibility describes an organization's commitment to conducting business in a course of action that benefits society and the environment rather than hurting them [3]. Corporate sustainability refers to business laws and procedures that strive to benefit society. CSR is based on the idea of pursuing other pro-social goals in addition to profit and growth. The trend toward CSR has had an impact on a 
number of areas [4]. Environmental sustainability, eco-efficiency, ethical sourcing, stakeholder participation, labour standards and conditions of employment, performance and employee relations, economic equality, gender balance, human rights, effective governance, and anti-corruption efforts are all common CSR objectives. CSR programmes, charity, and volunteer activities can all assist corporations in improving society while also enhancing their brands. CSR benefits both businesses and communities [5]. A completely accomplish CSR abstraction can furnish competitive advantages such as ameliorate access to finance and markets, higher improved productivity, accelerated skilled workforce, improved reputation in the market, higher consumer commitment, and improved decisionmaking and hazard procedures, to name a few [6]. In 2010, the International Organization for Standardization (ISO) published a set of voluntary assistance to help businesses implement social responsibility [7]. ISO 26000 provides suggestions rather than enforcing responsibilities because CSR is qualitative rather than quantitative, and its requirements cannot be verified [8]. ISO 26000, and from the other hand, is a framework that describes social responsibility and assists businesses in putting CSR concepts into practice. It must obey the constitution regardless of its size, type of business, or jurisdiction. ISO 26000 has received worldwide acceptability as a result of the involvement of various important stakeholders from around the world in its development [9].

\section{A COMPANY SHOULD INTRODUCE CSR BECAUSE :}

Many organizations trust that CSR is an important component of their brand identity, and that stakeholders will choose to do business with ethical companies [10]. As a result, CSR programmes may be an important proportion of a company's public relations strategy. Personal convictions, on the other hand, encourage some business owners to participate in CSR programmes. A CSR committee is required by Section 135 of the Companies (CSR) Rules, 2014, and Schedule VII of the Companies Act, 2013, as well as a minimum of $2 \%$ of average net earnings [11]. All enterprises having a net worth of Rs 500 crore or more, revenue of Rs 1,000 crore or more, or a net profit of Rs 5 crore or more in the preceding fiscal year are eligible to participate [12].

\section{CSR MOVEMENTS IN INDIA :}

Corporate India's CSR spending has risen since mandatory CSR requirements were implemented in 2014. Companies spent 47 percent more on CSR programmes in 2018 than they did in 2014-15, according to a survey [13]. The overall reporting percentage among qualifying organizations has always been 64 percent over the last four years. Investments were made Rs 52,000 crore, or 68 percent of the required CSR contribution, in the last four years. Listed companies in India spent Rs 10,000 crore for education, skill development, social welfare, healthcare, and environmental preservation, among other things. CSR contributions to the Prime Minister's Relief Fund surged by 139 percent over the previous year. Hunger, poverty, and healthcare got the most funding (38 percent), with ecological responsibility (12 percent) and regional development (12 percent) following closely behind (11 percent). Technology incubators, sports, the military, and programmes focused at alleviating inequality all received a small amount of funding [14].

\section{REVIEW OF LITREATURE :}

Below Table 1 contains the contribution by Various scholars for CSR initiatives were mostly carried out by Indian enterprises, with a focus on health, education, global compact, and women's empowerment. It will provide the organisation a positive image in the eyes of employees and customers.

Table 1: Contribution by different scholars for CSR

\begin{tabular}{|l|l|l|l|}
\hline $\begin{array}{l}\text { Sl. } \\
\text { No }\end{array}$ & \multicolumn{1}{|c|}{ Area } & \multicolumn{1}{c|}{ Contribution } & \multicolumn{1}{c|}{ Authors } \\
\hline 1 & $\begin{array}{l}\text { Environmental } \\
\text { revelations }\end{array}$ & $\begin{array}{l}\text { A conceptual framework was proposed as a } \\
\text { foundation for developing a company's strategy. This } \\
\text { article offers tools and metrics to help complex CSR } \\
\text { procedures become more transparent and managed. } \\
\text { The conceptual framework distinguishes between the } \\
\text { two variables of legitimacy and sense making/giving }\end{array}$ & $\begin{array}{l}\text { Shirodkar, V., et al } \\
\text { t2018] }\end{array}$ \\
\hline
\end{tabular}




\begin{tabular}{|c|c|c|c|}
\hline & & $\begin{array}{l}\text { in one dimension and the organisational environment } \\
\text { in the other. It also implies that a conceptual } \\
\text { framework enables a process to determine whether } \\
\text { the interaction is more motivated by legitimation or } \\
\text { by making sense, and whether the primary address is } \\
\text { the inner world or the organisational environment. }\end{array}$ & \\
\hline 2 & $\begin{array}{l}\text { Influence of } \\
\text { CSR }\end{array}$ & $\begin{array}{l}\text { In industries where there are incompatibilities } \\
\text { between corporate profit and social goals, or where } \\
\text { debates about justice can arise, CSR is a key part of } \\
\text { company strategy. Corporations can contribute to } \\
\text { CSR through creating social products for their } \\
\text { communities in a range of social sectors. A CSR } \\
\text { programme, he claims, may be a profitable } \\
\text { component of a company's strategy, minimising risk, } \\
\text { building brand equity, enhancing connections with } \\
\text { regulators, cutting the cost of capital, boosting human } \\
\text { relations and member of staff efficiency, and } \\
\text { maintaining long-term profitability relationships. }\end{array}$ & $\begin{array}{l}\text { Satapathy, J., et al } \\
\text { (2019). [16] }\end{array}$ \\
\hline 3 & $\begin{array}{l}\text { Measures } \\
\text { towards CSR }\end{array}$ & $\begin{array}{l}\text { Corporate sustainability is not a new word, according } \\
\text { to the research article. Only a few firms used to do } \\
\text { something for the betterment of society in the past. } \\
\text { They think that all customers are crucial to the } \\
\text { success of whatever business. The company will } \\
\text { surely be able to endure if they are better treated. The } \\
\text { goal of this research is to better acknowledge the role } \\
\text { of CSR in society's economic development. }\end{array}$ & $\begin{array}{l}\text { Vishwakarma, Vijay } \\
\text { (2019). [17] }\end{array}$ \\
\hline 4 & $\begin{array}{l}\text { Environmental } \\
\text { analysis }\end{array}$ & $\begin{array}{l}\text { The size of a company and the amount of CSR } \\
\text { variables are found to be positively related in this } \\
\text { study. As a result, the larger a company is, the more } \\
\text { resources and environmentally friendly corporate } \\
\text { environmental technologies it will be ready to invest } \\
\text { in. }\end{array}$ & $\begin{array}{l}\text { Saiprasad, D., et al } \\
\text { (2019). [18] }\end{array}$ \\
\hline 5 & $\begin{array}{l}\text { Legal } \\
\text { responsibilities }\end{array}$ & $\begin{array}{l}\text { Companies and other organisations that go above and } \\
\text { beyond their legal responsibilities to control their } \\
\text { impact on the environment and society are referred to } \\
\text { as CSR. This could incorporate how companies treat } \\
\text { their employees, suppliers, customers, and } \\
\text { communities, as well as their environmental policies. }\end{array}$ & $\begin{array}{l}\text { Pal, J., et al (2021). } \\
\text { [19]. }\end{array}$ \\
\hline
\end{tabular}

\section{RESEARCH GAP :}

Many studies have been conducted on CSR activities in diverse fields, this paper concentrates on MRPL Co's Corporate Social Practices since there is no study is available after 2018 and also study the focus area of social responsibility practices of the selected company, which are divided into four groups: environmental, social, economic, and operational practices, and to compare the focus areas of each sector.

\section{RESEARCH AGENDA :}

Understanding the concept of CSR and gaining insight into CSR activities in light of the MRPL Co. The current study is exploratory in nature, and it will look at the prospects of MRPL's social responsibility efforts, and strategies to make a positive contribution to society's development.

\section{COMPANY PROFILE :}

MRPL, a business unit of Oil and Natural Gas Corporation, is an oil refining company based in Mangalore. The distillery lies near Katipalla, north of Mangalore, and has been in operation since 1988. Five villages were forced to relocate due to the refinery: Bala, Kalavar, Kuthetoor, Katipalla, and 
Adyapadi. The modular design of the refinery allows it to process a wide range of API gravities while maintaining a high level of mechanization. MRPL is India's first refinery with two hydrocrackers generating premium diesel, with a design capacity of 15 million metric tonnes per year (high Cetane). A polypropylene plant with a capacity of 440,000 million tonnes per year is located nearby. It is also India's first refinery with two CCRs that generate high-octane unleaded gasoline. The refinery currently processes 14.65 million tonnes of oil per year. In 2020, the company's sales were 60,062.02 crore. MRPL became a public sector undertaking after ONGC bought a majority of the company's shares. As of June 2020, ONGC controlled 71.63 percent, HPCL 16.95 percent, and the balance was held by financial institutions and the general public. MRPL was recognised as a Miniratna by the Indian government in 2007. (Small jewel). MRPL was a joint venture oil refinery founded by Hindustan Petroleum Corporation Limited (HPCL), a public sector firm, and IRIL \& associates before being purchased by ONGC in March 2003. (Image courtesy of the AV Birla Group). In 1988, MRPL started operation with a processing capacity of 3.0 million metric tonnes annually, which was later raised to 15 million metric tonnes per year. By processing light to heavy, sour to sweet crudes with 24 to 46 API gravity, the refinery was designed to maximise middle distillates. On March 28, 2003, ONGC purchased the A.V. Birla Group's part of MRPL and injected additional equity capital of 600 crores, making MRPL an ONGC majority-owned subsidiary. The lenders also accepted ONGC's debt restructuring package (DRP), which comprises the conversion of up to 3,65,54,884 of the company's debts into equity. The shares assigned to the lenders under the DRP were then purchased by ONGC, boosting its interest in MRPL to 71.63 percent. On August 30, 2018, ONGC approved MRPL's amalgamation with HPCL. The Samrakshan brand is used to promote the company's CSR work. It embodies the Company's CSR policy's spirit and commitment to protect, conserve, and promote the social, cultural, and natural heritage and wealth in and around our business locations, as well as to support sustainable and equitable development [20].

\subsection{CSR at MRPL Company:}

According to Burke and Logsdon (1996), if CSR would be to become strategic for a corporation, it must be closely aligned with the organization's mission or vision, and management must give it top priority [21].

Stakeholder relations have been essential in the development of various impoverished regions inside India for MRPL Company. The idea of sustainable growth lies at the heart of both their business choices and Corporate Social Responsibility efforts. All CSR efforts are driven by a project-based strategy in accordance with rules from the Ministry of Public and Corporate Affairs of India. Strict commitment to numerous large-scale major projects and the commencement of additional projects designated under the MRPL's priority areas i.e.

- Achieving Company objectives for health and safety as well as environmental protection.

- Prevention, cleanliness, and access to safe drinking water are all important factors.

- Promote education and employment by improving vocational skills.

- Initiating and promoting environmental sustainability initiatives.

- Contribution to the Prime Minister's National Relief Fund or any other environmental relief fund established by the federal or state governments [21].

\subsection{Focus Areas of CSR in MRPL Company:}

In agreement with the terms of the Companies Act of 2013, MRPL's CSR initiatives will entail, among other things: In general terms, the five stated emphasis areas and activities are outlined below [22].

\section{SHIKSHA SAMRAKSHAN:}

$>$ Education-related activities, particularly in Anganwadis, government and government-aided schools.

$>$ Providing skill development and vocational training to unemployed rural youth, with a focus on women and candidates from SC, ST, OBC, and BPL families.

$>$ Providing infrastructure for the construction of more classrooms, restrooms, particularly for ladies, a kitchen, science and computer labs, sports facilities, and extracurricular activities for students' overall development. 
In educational institutions, providing nutritional food, clean drinking water, and sanitation facilities.

\section{AROGYA SAMRAKSHAN:}

$>$ In rural areas, health care is provided through the operation of Primary Health Centres.

$>$ Organizing medical camps in rural areas.

$>$ Organizing HIV/AIDS, Hepatitis, and other health-related campaigns.

$>$ Organizing camps for artificial limbs.

$>$ Providing infrastructure support to OHCs and government hospitals.

\section{BAHUJANA SAMRAKSHAN:}

$>$ Community halls near our operational locations receive infrastructure support.

$>$ Gender-sensitive projects, women's empowerment, and girl child development.

$>$ Initiatives aimed at the physically and mentally handicapped.

$>$ Mangalore Refinery \& Petrochemicals Ltd.'s initiatives for SC/ST communities.

Activities in the MRPL Rehab colony in support of the PDF communities

\section{PRAKRITI SAMRAKSHAN:}

$>$ Providing infrastructural support for the supply of drinking water to nearby villages Supporting projects in rural areas that provide safe drinking water and sanitation.

$>$ Groundwater recharging is component of water management.

$>$ Organizing environmental awareness programmes in schools and villages.

\section{SANSKRITI SAMRAKSHAN:}

$>$ Local historical and cultural artefacts, monuments, and heritage sites are all protected, etc.

$>$ Local artisans, craftsmen, musicians, artists, and their creative forms, among other things, are promoted in order to preserve local heritage, art, and culture.

\section{RESEARCH OBJECTIVES :}

The study's main purpose is to assess the notion of CSR activities and to discover how MRPL Co met its obligations to all stakeholders, including what specific actions, programmes, and strategies it devised and implemented. To look into the numerous CSR initiatives undertaken by MRPL Co ltd. To analyse strengths, weaknesses, opportunities and challenges of CSR activities of the MRPL Co ltd.

\section{RESEARCH METHODOLOGY :}

Secondary data for this study was gathered from a variety of sources, including the Minister of Corporate Affairs' official website, newspaper stories, research papers, and magazine articles. The traditional strategy, as we all know, concentrate on Corporate Philanthropy, which is elucidate as charity giving for social, cultural, and religious purposes, whereas the modern strategy prioritised long-term stakeholder attentiveness and sustainable development. The major goal of this research is to determine why is so important for firms. So why would they contribute to the country's economic prosperity? What tangible steps should the government take to encourage companies to participate in CSR programmes? We examined and analysed data from a variety of sources. No statistical methods or approaches are used because this paper doesn't want to establish a relationship between the variables; instead, discussion and analytical thinking is used to see how our country's policies have changed over time and what the consequences are.

\section{DATA ANALYSIS AND INTERPRETATION :}

Corporate Social Responsibility Practices by MRPL co limited of 3 years from the Fiscal year 2018-19 to 2020-21. Table-2 is showing MRPL organization's CSR funding in each activity in the fiscal year 2018-19, 2019-20, 2020-2021. 
International Journal of Case Studies in Business, IT, and Education

Table 2: Showing MRPL Co CSR funding in each activity

\begin{tabular}{|l|l|l|l|l|l|l|}
\hline $\begin{array}{l}\text { Sl. } \\
\text { No }\end{array}$ & \multicolumn{1}{|c|}{ Activities } & \multicolumn{2}{|c|}{ 2018-2019 } & \multicolumn{2}{c|}{ 2019-2020 } & 2020-2021 \\
\hline & $\begin{array}{l}\text { Expenditure } \\
\text { on project/ } \\
\text { programs } \\
\text { through } \\
\text { MRPL } \\
\text { company }\end{array}$ & $\begin{array}{l}\text { Amount } \\
\text { outlay } \\
\text { Project } \\
\text { wise (Rs in } \\
\text { lakhs) }\end{array}$ & $\begin{array}{l}\text { Cumulative } \\
\text { expenditure } \\
\text { up to the } \\
\text { reporting } \\
\text { period (Rs } \\
\text { in lakhs) }\end{array}$ & $\begin{array}{l}\text { Amount } \\
\text { outlay } \\
\text { project wise } \\
\text { (Rs in lakhs) }\end{array}$ & $\begin{array}{l}\text { Cumulative } \\
\text { expenditure } \\
\text { up to the } \\
\text { reporting } \\
\text { period (Rs in } \\
\text { lakhs) }\end{array}$ & $\begin{array}{l}\text { Amount } \\
\text { transferred to } \\
\text { Unspent CSR } \\
\text { Account for } \\
\text { the project as } \\
\text { per section } \\
135(6)\end{array}$ \\
\hline 1 & $\begin{array}{l}\text { Swachh } \\
\text { bharath } \\
\text { projects }\end{array}$ & 2873.77 & 937.18 & ------ & ------ & ------ \\
\hline 2 & $\begin{array}{l}\text { Shiksha } \\
\text { Samrakshan }\end{array}$ & 2376.65 & 1242.37 & 4736.59 & 3004.58 & 1261.97 \\
\hline 3 & $\begin{array}{l}\text { Arogya } \\
\text { Samrakshan }\end{array}$ & 1345.33 & 351.82 & 1477.18 & 1243.86 & 109.41 \\
\hline 4 & $\begin{array}{l}\text { Bahujan } \\
\text { Samrakshan }\end{array}$ & 997.42 & 613.1 & 5381.12 & 2919.75 & 1038.46 \\
\hline 5 & $\begin{array}{l}\text { Prakruthi } \\
\text { Samrakshan }\end{array}$ & 177 & ------- & 595.02 & 394.42 & 166.34 \\
\hline 6 & $\begin{array}{l}\text { Sanskruthi } \\
\text { Samrakshan }\end{array}$ & 35.81 & 1.15 & 70.09 & 46.29 & 41.52 \\
\hline 7 & Miscellaneous & ------ & ----- & ------ & ------ & ----- \\
\hline & $\begin{array}{l}\text { Funds yet to } \\
\text { committed }\end{array}$ & 1257 & 3145.62 & 7805.98 & 3145.62 & ------ \\
\hline & $\begin{array}{l}\text { GST (un- } \\
\text { utilised funds) }\end{array}$ & & 1257 & & \\
\hline & TOTAL & 9062.98 & 3132.00 & 12260 & 7608.90 & 2617.70 \\
\hline
\end{tabular}

Source: MRPL Annual report 2017-18, 2018-19, 2019-20[22]

Table 1 shows the MRPL Co's numerous CSR initiatives for fiscal year 2018-2019, the cash outlay project wise on Swachh Bharath projects is Rs 2873.77 lakhs, while the cumulative spending on Swachh Bharath projects up to the reporting period is Rs 937.18 lakhs. The total project expenditure on shiksha samrakshan is Rs 2376.65 lakhs, with a total expenditure of Rs 1242.37 lakhs up to the reporting period. The project outlay for Arogya Samrakshan is Rs 1345.33 lakhs, with a total expenditure of Rs 351.82 lakhs up to the reporting period. The total project expenditure on Bahujan samrakshan is Rs 997.42 lakhs, with a cumulative expenditure of Rs 613.1 lakhs up to the reporting period. The total project expenditure on Sanskruthi samrakshan is Rs 35.81 lakhs, with a cumulative expenditure of Rs 1.15 lakhs up to the reporting period. The overall amount spent by the company on project outlay is Rs 9062.98 , while the total amount spent on cumulative expenditure up to the reporting period is Rs 3132 lakhs. In the fiscal year 2019-2020, the amount spent on shiksha samrakshan is Rs 4736.59, with a total expenditure of Rs 3004.58 up to the reporting period. The project outlay for Arogya Samrakshan is Rs 1477.18 lakhs, with a total expenditure of Rs 1243.86 lakhs up to the reporting period. The total project outlay for Bahujan Samrakshan is Rs 5381.12 lakhs. and the total amount spent up to the reporting period is Rs 2919.75. The project outlay on prakruthi samrakshan is Rs 595.02, while the total expenditure up to the reporting date is Rs 394.42 lakhs. Sanskritic Samrakshan has a total project cost of Rs 70.09 lakhs, with a cumulative cost of Rs 46.29 lakhs up to the reporting period. The company has spent a total of Rs 12260 lakhs on project outlay, with a total of 7608.90 lakhs spent up to the reporting period. During fiscal year 2020-21, Rs 1261.97 lakhs went to an unspent CSR account for the Shiksha samrakshan project, whereas Rs 109.41 lakhs went to Arogya samrakshan. The total cost of the Bahujan samrakshan project was Rs 1038.46 lakhs. Samskrithi Samrakshan costs Rs 41.52. 


\section{SWOC ANALYSIS :}

A SWOC analysis, which is an important strategic planning approach, can be used to accomplish a situational analysis. It can help to discover the current Strengths (S), Weaknesses (W), Opportunities (O), and Threats (T) [23][24].

\section{STRENGTHS}

1. CSR strengthens public confidence. Consumers are more willing to spend money with a company that supports and participates in activities that benefit society.

2.CSR Improves brand image and reputation of the organization.

3. CSR improves investement opportunities of MRPL company.

4. CSR increases Sustainable development of the company

\section{WEAKNESSES}

1. Between businesses and the general population, there is a lack of visibility.

2. Between MRPL company and the general public, there is a lack of visibility

3. Due to a lack of judgement within a time constraint, other people's efforts are duplicated.

4. In MRPL Co there are no basic mechanisms in place to manage CSR. place to manage CSR.

5. The limited implementation of International CSR standards by organization

\section{SWOC}

\section{OPPORTUNITIES}

1. Understanding the true facts about the environment is beneficial to both business and society.

2. Stronger influence of the company's brand image on the minds of customers.

3. Incorporating responsible entrepreneurship into the educational process helps foster the formation of a relevant culture among future managers and organisations.

\section{THREATS}

1. There are just not enough public policies to encourage CSR

2. There is a lack of consistency in the legal structure.

3. Lack of awareness and interaction of citizens and customers

4. Lack of knowledge about social and cultural matters

4. Creating new business opportunities in a variety of fields.

Fig. 1: SWOC Analysis of CSR activities In MRPL Co showing the current economic environment in which the MRPL Company operates.

Source: Compiled by researcher

\section{FINDINGS :}

1. The number of stakeholders in a society has always been a factor in business. CSR has become a popular and strong tool for fostering social commitments as well as company reputation. Responsibility of Corporations and other profit-making enterprises towards society is known as Corporate Social Responsibility (CSR). What it really is a voluntary effort by businesses to improve society and the environment. Companies must thus evaluate and emphasize CSR efforts as an integral part of their daily operations

2. According to the findings of the research, business units have mostly concentrated on the following activities: 
- Swachh Bharat Kosh is a Central Government initiative to promote cleanliness and make safe drinking water available. This includes eradicating hunger, poverty, and malnutrition. It also promotes preventative health care and sanitation.

- Aims at promoting learning, particularly special education and the development of occupational vocation skills. Particularly for children, women, the elderly, and individuals with disabilities, as well as programmes aiming at strengthening people's living standards.

- Promoting rural sports, as well as sports that are nationally recognized, the Paralympics, and Olympic events.

- Rural development projects

3. Some discrepancies exist in CSR activity disclosure patterns. Each business unit has provided all of the essential information, but they are still lacking a standard structure for disclosure.

\section{SUGGESTIONS :}

1. People are concerned about corporate responsibility for a variety of reasons. As a result, businesses must provide statistics on corporate sustainability in both quantity and quality. As a result, corporate social responsibility statistics must be precise (CSR).

2. Companies should disseminate their CSR initiatives to a broad audience. It has a good chance of increasing the company's profits in the future.

3. To improve the company's financial success while simultaneously expanding the benefits to recipients, CSR programmes must be well-structured for the long run. The corporation may be able to serve the community as a whole through CSR efforts.

4. Businesses must boost customer trust, decrease risks, and create long-term value by establishing a positive relationship between CSR and profitability.

5. Businesses are responsible for informing the general public and other stakeholders about their commitments. Communities should be involved in the planning, organising, implementing, and evaluating of CSR projects by businesses. It will encourage constructive relationships among stakeholders.

6. Companies must consider issues such as education, health, childcare, and other issues of the slum and poor segments of society in rural areas while focusing on the demands of urban areas.

7. Businesses should maintain solid governance in order to promote employee-employer relations and, as a result, financial performance.

8. Designing, financing, implementing, and documenting CSR programmes, as well as monitoring and assessing them, are all skills that CSR workers must learn.

9. Agriculture is India's most important and significant industry. As a result, significantly more agricultural investment is required.

\section{CONCLUSION :}

To summarise, corporate social responsibility (CSR) is an increasingly significant aspect of business. Companies are exploiting societies and the environment's resources. As a result, they must assume some level of responsibility for them. Consumers prefer companies who engage in CSR projects and are willing to pay more for their products. To be honest, corporate social responsibility isn't the most important aspect in determining a company's sales and profits. A multitude of other elements have an impact on a company's sales and net profit. According to the study's findings, CSR has no bearing on a company's sales or net profit. In certain circumstances, a mixture of both or none of them may be effective. The organisational structure of a company, the governing body's decision-making processes, and its overall performance are all essential considerations. The company will be able to expand its operations if it succeeds in the worldwide market.

\section{REFERENCE :}

[1] Verma, A., \& Kumar, C. V. (2014). An analysis of CSR expenditure by Indian companies. Indian Journal of Corporate Governance, 7(2), 82-94.

Google Scholar $\chi^{\top}$ 
[2] Kumar, N. (2019). Corporate Social Responsibility: An analysis of impact and challenges in India. International Journal of Social Sciences Management and Entrepreneurship (IJSSME), 3(2), 54-63.

Google Scholar X

[3] Mukherjee, A., \& Bird, R. (2016). Analysis of mandatory CSR expenditure in India: a survey. International Journal of Corporate Governance, 7(1), 32-59.

Google Scholar X

[4] Nash, D R (2012). CSR Contributions of Maharatna Companies of India. Asian journal of research in Business Economics and Management 2(4), 105-112. Google Scholar $X^{\top}$

[5] Gautam, R., \& Singh, A. (2010). Corporate social responsibility practices in India: A study of top 500 companies. Global Business and Management Research: An International Journal, 2(1), 4156.

Google Scholar X

[6] https://www.downtoearth.org.in/blog/governance/corporate-social-responsibility-practices-in-thetimes-of-covid-19-a-study-of-india-s-bfsi-sector-74583 retrieved on 23/7/2021.

[7] Gao, Y. (2011). CSR in an emerging country: a content analysis of CSR reports of listed companies. Baltic Journal of management, 6(2), 263-291.

Google Scholar $x^{\top}$

[8] Gupta, O., \& Gupta, K. (2019). CSR in India: the companies act and its implications. Journal of Contemporary Management Research, 13(1), 1-23.

Google Scholar $X^{7}$

[9] Kaur, S. (2018). A Study on The Impact of CSR Performance on The Financial Performance of Indian Service Sector. International Journal of Business Competition and Growth, 6(2), 115-127. Google Scholar ${ }^{\top}$

[10] Sekaran, S. (2021). An Analysis on the Development of Corporate Social Responsibility (CSR). International Journal of Recent Advances in Multidisciplinary Topics, 2(6), 212-214. Google Scholar X'

[11] Kapoor, G. K., \& Dhamija, S. (2017). Mandatory CSR spending-Indian experience. Emerging Economy Studies, 3(1), 98-112.

Google Scholar $\chi^{7}$

[12] Hole, Y., Pawar-Hole, S., \& Bendale, S. (2019). Corporate Social Responsibility (CSR) in India: a conceptual framework. GIS Business, 14(6), 330-340.

Google Scholar $\chi^{\top}$

[13] Arora, B., \& Puranic, R. (2004). A Review of Corporate Social Responsibility in India. Society For International Development, 47(3), 93-100.

Google Scholar X

[14] Bird, R., Duppati, G., \& Mukherjee, A. (2016). Corporate social responsibility and firm market performance: a study of Indian listed companies. International Journal of Business Governance and Ethics, 11(1), 68-88.

Google Scholar $X^{7}$

[15] Shirodkar, V., Beddewela, E., \& Richter, U. H. (2018). Firm-level determinants of political CSR in emerging economies: Evidence from India. Journal of business ethics, 148(3), 673-688.

Google Scholar ${ }^{\top}$

[16] Satapathy, J., \& Paltasingh, T. (2019). CSR in India: a journey from compassion to commitment. Asian Journal of Business Ethics, 8(2), 225-240.

Google Scholar $\chi^{\top}$ 
[17] Vishwakarma, V. (2019). Corporate Social Responsibility (A Literature Review). Shanlax International Journal of Management, 7(1), 36- 41.

Google Scholar $x^{\nearrow}$

[18] Saiprasad, D., \& Padmaja, P. V. A Study on CSR And Its Impact on Financial Performance of Listed Companies in India. IJEMR, 9(1), 1-7.

Google Scholar $\chi^{\top}$

[19] Pal, J., \& Dutta, U. K. (2021) A Study on The CSR Spending by The Leading Companies in India After the New Companies Act. Time's Journey, 5(1), 51-61.

Google Scholar $\chi^{\top}$

[20] https://www.mrpl.co.in/ retrieved on 3/8/2021.

[21] http://shellmrpl.co.in/investors-information/csr/csr-corporate-social-responsibility/ retrieved on $15 / 8 / 2021$

[22] https://admin.mrpl.co.in/img/UploadedFiles/CSR/Files/English/214be86425644101b63b68b44 e090457.pdf retrieved on 15/8/2021.

[23] Aithal, P. S., \& Kumar, P. M. (2015). Applying SWOC analysis to an institution of higher education. International Journal of Management, IT and Engineering, 5(7), 231-247. Google Scholar X

[24] Reddy, B. \& Aithal, P. S. (2020). RBI Distributed Ledger Technology and Blockchain-A Future of Decentralized India. International Journal of Management, Technology, and Social Sciences, 5(1), 1-10.

Google Scholar X 